\title{
PERBANDINGAN YIELD NERACA MASSA HASIL PRETREATMENT TIGA JENIS LIMBAH LIGNOSELULOSA DALAM MEMPRODUKSI POLISAKARIDA MENGGUNAKAN TEKNIK KIMIAWI
}

\author{
Gading Wilda Aniriani ${ }^{1 *}$, Nurul Fitria Apriliani ${ }^{2)}$ \\ ${ }^{1)}$ Program Studi Ilmu Lingkungan, Fakultas Teknik, Universitas Islam Lamongan \\ ${ }^{2)}$ Program Studi Teknik Informatika, Fakultas Teknik, Universitas Islam Lamongan \\ *) Coresponding author : gading.wildaa@gmail.com \\ email : gading.wildaa@gmail.com; nfitria.apriliani@gmail.com
}

\begin{abstract}
ABSTRAK
Limbah lignoselulosa merupakan jenis limbah yang mengandung lignin, selulosa dan hemiselulosa (xilan). Pada lignoselulosa, senyawa yang dapat dimanfaatkan adalah hemiselulosa dan selulosa, sedangkan lignin dihilangkan. Hemiselulosa dan selulosa sebagai polisakarida dapat digunakan sebagai substrat dalam produksi enzim maupun hidrolisis secara kimia, proses tersebut dilakukan untuk mendapatkan gula yang lebih sederhana. Penelitian sebelumnya telah dilakukan ekstraksi xilan dari ampas tebu, hasil samping dari ekstraksi tersebut adalah selulosa. Oleh karena itu, penelitian ini telah membandingkan hasil ekstraksi xilan dan selulosa dalam satu jenis limbah dan membandingkan hasil keduanya diantara 3 jenis limbah lignoselulosa menggunakan metode yang sama. Penelitian ini bertujuan untuk mengekstraksi polisakarida xilan dan selulosa yang terkandung di dalam limbah ampas tebu, tongkol jagung dan jerami padi. Metode penelitian yang digunakan adalah pretreatment secara kimiawi yakni delignifikasi dengan $1 \% \mathrm{NaOCl}(\mathrm{v} / \mathrm{v})$, ekstraksi xilan dan selulosa dengan metode alkali menggunakan $15 \% \mathrm{NaOH}$ pekat dan purifikasi xilan dengan $4 \% \mathrm{NaOH}(\mathrm{v} / \mathrm{v})$. Adapun target yang telah dicapai adalah perolehan polisakarida terbanyak akan digunakan sebagai bahan utama untuk memproduksi enzim. Hasil perolehan yield pada masing-masing neraca massa menunjukkan bahwa, jumlah rendemen xilan terbanyak yaitu jerami sebanyak $110 \mathrm{~g}$ dengan penurunan massa dari proses sebelumnya sebesar $61,5 \%$, sedangkan untuk rendemen selulosa diperoleh juga oleh jerami yaitu sebanyak $330 \mathrm{~g}$ dengan penurunan massa dari proses sebelumnya sebesar 39,5\% . Hal tersebut menunjukkan bahwa jumlah terbanyak pada rendemen xilan berbanding lurus dengan jumlah selulosa. Kesimpulan tersebut di perkuat dengan hasil pada dua jenis limbah lainnya, yakni berbanding lurus. Perolehan rendemen hasil purifikasi terbanyak yaitu ampas tebu (bagas) sebesar 86 gr dengan persentase penurunan massa hanya sebesar $14 \%$.
\end{abstract}

Kata kunci: Lignoselulosa, Delignifikasi, Ekstraksi, Xilan, Selulosa.

\section{COMPARISON OF YIELD BALANCE MASS RESULT OF PRETREATMENTT THREE TYPES OF LIGNOSELULOSA WASTE IN PRODUCING POLYSACCHARIDE USING CHEMICAL ENGINEERING}

\begin{abstract}
Lignocellulosic waste is a type of waste containing lignin, cellulose and hemicellulose (xylan). In lignocellulose, the compounds that can be utilized are hemicellulose and cellulose, whereas lignin is removed. Hemicellulose and cellulose as polysaccharides can be used as substrates in the production of enzymes and hydrolysis chemically, the process is carried out to obtain simpler sugars. In a previous research, the extraction of xylan from bagasse, a by-product of the extraction, was cellulose. Therefore, this research compared the results of xylan and cellulose extraction in one type of waste and compare the results of the two between 3 types of lignocellulosic waste using the same method. This research aims to extract polysaccharide xylan and cellulose contained in waste bagasse, corn cob and rice straw. The research method used was chemical pretreatment ie delignification with $1 \% \mathrm{NaOCl}(\mathrm{v} / \mathrm{v})$, xylan extraction and cellulose by alkali method using $15 \%$ concentrated $\mathrm{NaOH}$ and purification of xylan with $4 \% \mathrm{NaOH}(\mathrm{v} / \mathrm{v})$. The target to be achieved is the acquisition of the most polysaccharides will be used as the main
\end{abstract}


ingredient for producing enzymes. The yield of mass balance shows that the highest amount of xylan content is $110 \mathrm{~g}$ with the mass decrease from the previous process of $61.5 \%$, while for cellulose rendemen is also obtained by straw as much as $330 \mathrm{~g}$ with the decrease of mass from process previously amounted to $39.5 \%$. This shows that the largest amount of xylan content is proportional to the amount of cellulose. The conclusions are reinforced with the results of two other types of waste, which are directly proportional. The highest yield of purification result is bagasse equal to $86 \mathrm{gr}$ with percentage of mass decrease only $14 \%$.

Keywords: Lignocellulose, Delignification, Extraction, Xylan, Cellulose.

\section{PENDAHULUAN}

dalam $\begin{gathered}\text { Polisakarida digunakan secara luas } \\ \text { aplikasi bioteknologi. Adapun }\end{gathered}$ kegunaan polisakarida yaitu dapat digunakan sebagai substrat dalam proses hidrolisis baik secara enzimatik maupun kimiawi. Hidrolisis yang sempurna dari selulosa akan menghasilkan glukosa, sedangkan hemiselulosa menghasilkan beberapa monomer gula pentose (C5) dan heksosa (C6). Selulosa secara alami diikat oleh hemiselulosa dan dilindungi oleh lignin, oleh karena itu disebut dengan lignoselulosa. Menurut Iranmahboob dkk (2002) adanya senyawa pengikat lignin inilah yang menyebabkan bahan-bahan lignoselulosa sulit untuk dihidrolisis. Oleh sebab itu pretreatment merupakan proses yang sangat penting dalam mempengaruhi perolehan yield polisakarida.

Polisakarida atau gula kompleks dapat diperoleh dari bahan pangan (seperti singkong, kedelai, jagung dll), limbah lignoselulosa, tebu (sugarcane) dan lainlain. Penggunaan limbah lignoselulosa sebagai biomassa tidak akan bersaing dengan ketahanan pangan, oleh karena itu biomassa dari lignoselulosa dapat digunakan sebagai alternatif. Selain itu pemanfaatan limbah ini dinilai cukup murah karena memanfaatkan material sisa yang sudah tidak terpakai, meningkatkan nilai ekonomis suatu limbah, dan ketersediaannya yang melimpah. Riyanti (2008) menyatakan bahwa Indonesia memiliki potensi biomassa yang tinggi dan dapat dimanfaatkan.

Proses untuk memperolah yield polisakarida pada bahan limbah lignoselulosa meliputi tiga tahap dasar yakni: preparasi bahan dasar, proses delignifikasi, dan proses ekstraksi. Pretreatment bertujuan untuk memecah lignin (delignifikasi) dan merusak struktur kristal yang mengikat selulosa (Sudiyani dkk. 2010), selain itu juga bertujuan untuk memecah bahan-bahan lignoselulosa baik dari segi struktur dan ukuran. Selulosa secara alami diikat oleh hemiselulosa dan dilindungi oleh lignin, oleh karena itu disebut dengan lignoselulosa. Menurut Iranmahboob dkk. (2002) adanya senyawa pengikat lignin inilah yang menyebabkan bahan-bahan lignoselulosa sulit untuk diekstraksi. Oleh sebab itu pretreatment merupakan proses yang sangat penting dalam mempengaruhi perolehan yield polisakarida.

Penelitian ini dilakukan dengan mempretreatment limbah jerami padi, ampas tebu dan tongkol jagung menjadi gula kompleks (polisakarida) xilan dan selulosa. Proses pretreatment meliputi, preparasi substrat, delignifikasi, ekstraksi polisakarida dan purifikasi.

\section{TINJAUAN PUSTAKA}

Bahan lignoselulosa tersedia melimpah dalam bentuk limbah pertanian dan industri (Riyanti 2008). Komponen utama dari lignoselulosa adalah selulosa, sedangkan komponen melimpah kedua adalah hemiselulosa yang terdiri dari gulagula kompleks (polisakarida) seperti xilan (dari ampas tebu, jerami padi dan tongkol jagung) dan manan (dari tandan kosong kelapa sawit). Komponen ketiga adalah lignin. Selulosa secara alami diikat oleh hemiselulosa dan dilindungi oleh lignin, oleh karena itu disebut dengan lignoselulosa. Proses enzimatik dalam hidrolisis dapat dipermudah dengan adanya pretreatment yang dapat

Pretreatment merusak dinding sel tanaman dan mempermudah akses enzim pada polisakarida tanaman (Gray dkk. 2006). Proses pretreatment pada penelitian ini bertujuan untuk mempermudah proses untuk mencapai tahap hidrolisis menggunakan 
enzim. Gray dkk. (2006) menyatakan bahwa biomassa yang tidak ditreatment akan bersifat recalcitrant pada proses pemecahan oleh enzim. Proses pretreatment meliputi preparasi limbah, delignifikasi, ekstraksi polisakarida dan purifikasi (ekstraksi ulang).

\section{Delignifikasi}

Delignifikasi merupakan proses penghilangan komponen lignin dari tanaman. Proses delignifikasi dapat dilakukan dengan beberapa cara, yakni secara fisik, kimiawi dan biologi. Delignifikasi secara kimiawi adalah metode yang paling efektif dalam menghilangkan lignin, karena secara fisik biaya yang dikeluarkan mahal sedangkan secara biologi dibutuhkan waktu yang sangat lama (Iranmahboob dkk, 2002). Metode delignifikasi diuji secara oksidatif, dengan menggunakan Sodium hipoklorit $(\mathrm{NaOCl})$ sebagai oksidator. Beberapa oksidator lain, termasuk ozon, hidrogen peroksida, hipoklorit, klorin, klorin dioksida, dan asam asetat telah dilakukan untuk perlakuan kimia biomassa (Chapman 2003). Sodium hipoklorit secara luas digunakan sebagai campuran minuman dan treatment limbah. Pelarut tersebut sering dihubungkan sebagai cairan pemutih atau soda pemutih (Lee 2003).

\section{Ekstraksi}

Ekstraksi dilakukan secara kimiawi, dimana polisakarida yang terikat dipisahkan. Adapun beberapa pelarut yang dapat memisahkan xilan/selulosa. Proses pemisahan xilan dengan selulosa menggunakan pelarut asam dan basa.

Xilan sangat larut dalam pelarut basa, oleh karena itu saat di netralkan xilan akan terbawa dalam fase cair dan menyisakan selulosa sebagai endapannya (Tabel 1).

Tabel 1. Kelarutan xilan dalam beberapa pelarut

\begin{tabular}{ll}
\hline \multicolumn{1}{c}{ Pelarut } & \multicolumn{1}{c}{ Kelarutan } \\
\hline $\mathrm{NaOH} 1 \%$ & +++ (sangat larut) \\
Air Panas $\left(90^{\circ} \mathrm{C}\right)$ & ++ (larut) \\
Air Dingin $\left(27^{\circ} \mathrm{C}\right)$ & + (sedikit larut) \\
$\mathrm{HCl} \mathrm{1N}$ & - (tidak larut) \\
\hline
\end{tabular}

(Sumber: Richana et al. (2007)).

\section{METODE PENELITIAN}

Penelitian dilakukan pada bulan Juni sampai Agustus 2017 di Laboratorium Terpadu Technopark Universitas Islam Lamongan dan Unit Layanan Pengujian Fakultas Farmasi Universitas Airlangga Surabaya.

Substrat polisakarida didapatkan menggunakan pengujian skala labolatorium. Metode penelitian meliputi preparasi limbah, delignifikasi, ekstraksi polisakarida, dan purifikasi.

\section{Preparasi Limbah}

Limbah jerami padi, tongkol jagung dan ampas tebu dikeringkan di bawah terik matahari sampai mendapatkan berat kering, dipotong menjadi ukuran kecil kemudian di dihancurkan dengan mesing giling. Setelah menjadi serbuk kemudian dilakukan pembubukan lolos saringan $40 \mathrm{mesh}$, hasil modifikasi dari Lee (2003). Kandungan total selulosa, hemiselulosa dan lignin bagas didapatkan dari analisis proksimat dan analisis serat.

\section{Delignifikasi}

Delignifikasi serbuk limbah dilakukan menggunakan pelarut natrium hipoklorit $(\mathrm{NaOCl})$ karena pelarut tersebut mengandung ion-ion hipoklorit yang mampu memecah ikatan karbon dalam struktur lignin. Proses delignifikasi dilakukan selama 5 jam pada suhu ruang, yaitu dengan merendam serbuk limbah dengan larutan $1 \%$ $\mathrm{NaOCl}$ Padatan hasil proses perendaman kemudian dicuci sampai bau $\mathrm{NaOCl}$ nya hilang, lalu dilakukan proses penyaringan untuk membuang air yang membawa lignin. Bubuk limbah kemudian dikeringkan di bawah terik matahari sampai mencapai berat kering. Hasil delignifikasi dianalisis proksimat dan analisis serat kembali untuk mendapatkan kandungan selulosa, hemiselulosa dan lignin setelah delignifikasi.

\section{Ekstraksi Polisakarida}

Metode ekstraksi xilan/selulosa menggunakan metode alkali. Padatan hasil delignifikasi direndam dalam $15 \% \quad \mathrm{NaOH}$ pada suhu ruang selama 24 jam untuk mendapatkan ekstrak xilan/selulosa. Setelah 
24 jam dilakukan penyaringan dengan menggunakan kain saring, filtrat (suspensi) yang dihasilkan dari proses ekstraksi diukur pHnya kemudian dinetralkan dengan menggunakan $37 \% \mathrm{HCl}$ sampai netral $(\mathrm{pH}$ 7). Suspensi kemudian di sentrifuge pada 6000 rpm selama 15 menit. Supernatan mengandung ekstrak xilan, sedangkan endapan mengandung selulosa. Xilan yang larut dalam supernatan dibersihkan dengan menambahkan etanol 98\%. Etanol ditambahkan pada supernatan dengan perbandingan supernatan-etanol adalah 1:3 kemudian dilakukan penyaringan untuk memisahkan filtrate dan endapan. Hasil dari sentrifugasi tersebut adalah endapan yang mengandung xilan.

\section{Purifikasi xilan}

Purifikasi ekstrak xilan/selulosa
dilakukan dengan terlebih dahulu dengan
merendam endapan xilan/selulosa kering
dalam aquades 1:12,5 b/v, kemudian
disentrifugasi pada $6000 \mathrm{rpm}$ selama 30
menit. Endapan yang dihasilkan direndam
dalam $4 \% \mathrm{NaOH}$ pH 7 , kemudian disaring
untuk membuang ampas. Penetralan pH
sampai netral dengan 37\% HCl. Suspensi
kemudian disentrifugasi kembali pada 4000
rpm selama 30 menit. Xilan murni
didapatkan dari endapan yang sudah
dikeringkan pada suhu $50^{\circ} \mathrm{C}$ selama 72 jam.

\section{HASIL DAN PEMBAHASAN}

\section{Preparasi Limbah Lignoselulosa}

Limbah lignoselulosa didapatkan dari beberapa tempat yang berbeda. Limbah jenis jerami dan tongkol jagung didapatkan dari hasil samping panen sawah dibeberapa titik lokasi di Lamongan, sedangkan limbah ampas tebu didapatkan dari pabrik gula PT. Kayu Tebu Mas Ngimbang Lamongan. Proses pretreatment membutuhkan masingmasing sebanyak $1000 \mathrm{~g}$ serbuk kering. Berikut ialah hasil proses preparasi limbah secara bertahap sebelum dilakukan pretreatment yang disajikan dalam Gambar 1.

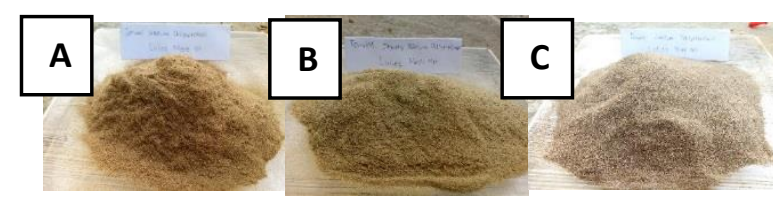

Gambar 1. Hasil preparasi masing-masing limbah yang telah diayak dengan ukuran partikel 40 mesh. A) Serbuk jerami, B) Serbuk tongkol jagung dan C) Serbuk bagas tebu.

Pengeringan sampel dilakukan untuk memudahkan proses penggilingan karena biomassa mengandung air $48-52 \%$. Penggilingan biomassa menjadi serbuk dilakukan agar proses perendaman oleh larutan $\mathrm{NaOCl}$ (delignifikasi) dan $\mathrm{NaOH}$ (ekstraksi xilan) menjadi lebih mudah homogen sehingga penetrasi pereaksi sempurna dan reaksi seragam. Hasil dari proses penggilingan biasanya belum homogen dan masih kasar, maka sampel perlu diayak untuk menghilangkan bahan yang masih kasar sehingga dapat digiling kembali. Bubuk bagas hasil gilingan kemudian diayak pada saringan mesh 40 . Tidak ada aturan umum perihal ukuran partikel yang paling baik yang digunakan dalam analisis kayu, tetapi ukuran partikel yang lazim berkisar antara 40-80 mesh atau antara 0,05 dan 0,4 mm. Hasil dari proses preparasi fisik biomassa kemudian dilakukan analisis proksimat dan serat.

\section{Delignifikasi}

Pengurangan berat biomassa dalam proses delignifikasi dari tiga jenis limbah berdasarkan hasil neraca massa terbanyak yaitu bagas tebu, sedangkan yang mengalami pengurangan paling sedikit yakni tongkol jagung (Tabel 2). Penurunan tersebut diduga karena hilangnya material selama proses penyaringan dan atau komponen lignin maupun hemiselulosa yang terbawa oleh pelarut Sodium hipoklorit ( $\mathrm{NaOCL})$. 
Tabel 2. Hasil dari neraca massa tahapan pretreatment pada masing-masing limbah lignoselulosa.

\begin{tabular}{|c|c|c|c|c|c|}
\hline \multirow{3}{*}{$\begin{array}{l}\text { Sampel } \\
\text { Limbah }\end{array}$} & \multicolumn{5}{|c|}{ Tahapan perlakuan (g) } \\
\hline & \multirow[b]{2}{*}{ M1 } & \multirow[b]{2}{*}{ M2 } & \multicolumn{2}{|c|}{ M3 } & \multirow[b]{2}{*}{ M4 } \\
\hline & & & $\begin{array}{l}\text { Xila } \\
n\end{array}$ & $\begin{array}{l}\text { Selulo } \\
\text { sa }\end{array}$ & \\
\hline Jerami & 1000 & 725 & 110 & 330 & 85 \\
\hline $\begin{array}{l}\text { Tongkol } \\
\text { Jagung }\end{array}$ & 1000 & 860 & 75 & 195 & 40 \\
\hline $\begin{array}{l}\text { Ampas } \\
\text { Tebu } \\
\text { (Bagas) }\end{array}$ & 1000 & 704 & 100 & 200 & 86 \\
\hline
\end{tabular}

Ket:

M1 = berat awal limbah; M2 = delignifikasi; M3 = ekstraksi; M4 = pemurnian xilan

Tabel 3. Persentase penurunan pada tahapan pretreatment pada masing-masing limbah lignoselulosa.

\begin{tabular}{|c|c|c|c|c|c|}
\hline \multirow{3}{*}{$\begin{array}{l}\text { Sampel } \\
\text { Limbah }\end{array}$} & \multicolumn{5}{|c|}{ Tahapan perlakuan (\%) } \\
\hline & \multirow[b]{2}{*}{ M1 } & \multirow[b]{2}{*}{ M2 } & \multicolumn{2}{|c|}{ M3 } & \multirow[b]{2}{*}{ M4 } \\
\hline & & & Xilan & $\begin{array}{l}\text { Selul } \\
\text { osa }\end{array}$ & \\
\hline Jerami & 100 & 27,5 & 61,5 & 39,5 & 25 \\
\hline $\begin{array}{l}\text { Tongkol } \\
\text { Jagung }\end{array}$ & 100 & 14 & 78,5 & 66,5 & 35 \\
\hline $\begin{array}{l}\text { Ampas } \\
\text { Tebu } \\
\text { (Bagas) }\end{array}$ & 100 & 29,6 & 60,4 & 50,4 & 14 \\
\hline
\end{tabular}

Ket:

M1 = berat awal limbah; M2 = delignifikasi; M3 = ekstraksi; M4 = pemurnian xilan

Su et al. (2012) hasil delignifikasi dengan $10 \% \mathrm{NaOH}$ menghasilkan degradasi lignin sebesar $62 \%$. Perbandingan hasil tersebut mengindikasikan bahwa penggunaan $\mathrm{NaOCl}$ lebih efektif dari pada $\mathrm{NaOH}$ sebagai pendegradasi lignin. Selain itu penggunaan $\mathrm{NaOH}$ sebagai pendegradasi lignin justru akan melarutkan xilan yang akan diekstraksi pada tahap selanjutnya.

Penurunan terjadi karena hilangnya material selama proses penyaringan hasil delignifikasi (Tabel 2), komponen lignin maupun polisakarida yang terlarut di dalam pelarut. Semakin tinggi konsentrasi yang digunakan maka semakin tinggi pula tingkat kelarutan xilan. Bagian yang larut dalam media alkali tetapi dapat mengendap dari larutan yang dinetralkan disebut $\beta$-selulosa dan untuk selulosa yang tidak larut dalam larutan $\mathrm{NaOH}$ kuat ialah jenis $\alpha$-selulosa. Selain melakukan pemisahan secara mekanik yakni sentrifugasi, suspensi hasil ekstraksi masih perlu difraksinasi untuk memisahkan hemiselulosa xilan dari fraksi pengotor seperti $\alpha$-selulosa dan $\beta$-selulosa.
Sebanyak $\quad 50 \quad \mathrm{~g}$ jerami kombinasi perbandingan $\quad 0,5 \% \quad \mathrm{NaOCl}$ dan etanol:supernatant (1:3) menghasilkan rendemen xilan tertinggi sebesar 12,95\% (Richana et al. 2007). Perbedaan hasil rendemen xilan dalam penelitian tersebut diduga karena perbedaan biomassa dan perbedaan jumlah jerami yang digunakan terlalu banyak $(1000 \mathrm{~g})$, sehingga proses pengikatan xilan kurang merata dan dibutuhkan waktu perendaman yang lebih lama.

Beberapa oksidator lain, termasuk ozon, hidrogen peroksida, hipoklorit, klorin, klorin dioksida, dan asam asetat telah dilakukan untuk delignifikasi secara kimia pada biomassa (Chapman 2003). Berbeda dengan asam hipoklor dan klorin yang tidak terurai, ion hipoklorit yang digunakaan dalam penelitian ini $(\mathrm{NaOCl})$ merupakan elektrofil dan bermuatan negatif sebagai nukleofil yang dapat menyerang tempattempat bermuatan positif dalam substrat. Selain itu, ion hipoklorit merupakan oksidan kuat yang dapat memecah ikatan-ikatan karbon dengan karbon dalam struktur kayu. Oksidasi dapat meningkatkan jumlah molekul positif dengan penghilangan satu atau lebih elektron dari atom atau ion. Ionion hipoklorit akan mendorong terjadinya pemecahan ikatan pada gugus eter karena adanya pelepasan gugus-gugus hidroksil fenol. Pada kompleks lignin-hemiselulosa maupun lignin-selulosa terdapat ikatan ester atau eter maupun glikosida yang dapat dipecah oleh alkali. Penggunaan larutan alkali di dalam delignifikasi karena kandungan alkali dapat memecah ikatan ester dari xilan melalui ikatan asam 4-Ometil glukoronat.

Menjelang akhir delignifikasi dapat terjadi kehilangan polisakarida, sehingga mengurangi rendemen. Lignin yang terdegradasi larut dalam media delignifikasi dalam bentuk senyawa keton. Penggunaan konsentrasi yang kecil yaitu $1 \% \quad \mathrm{NaOCl}$ bertujuan untuk tidak banyak melarutkan hemiselulosa (xilan). Pretreatment pada bahan lignoselulosa dapat menghilangkan lignin dan hemiselulosa, mengurangi kristal selulosa, dan meningkatkan porositas material (Sun and Cheng 2002). Hasil penelitian Richana (2007), konsentrasi $\mathrm{NaOCl}$ yang tinggi $(7,5 \%)$ dapat membuat hemiselulosa hilang atau larut dalam proses 
delignifikasi dan sebaliknya pada konsentrasi yang rendah hanya sebagian hemiselulosa yang larut. Demikian pula dengan hasil penelitian Lee (2003), persentase penurunan lignin bagas tebu dengan konsentrasi $1 \% \quad \mathrm{NaOCl}$ hanya menghilangkan sebesar 24,4 \% dibandingkan dengan konsentrasi $5 \%$ $\mathrm{NaOCl}$ mencapai $63,3 \%$. Oleh karena itu penggunaan konsentrasi $1 \% \mathrm{NaOCl}$ dalam penelitian ini bertujuan untuk memaksimalkan proses penghilangan lignin, tanpa mengurangi xilan (hemiselulosa). Dimana xilan dalam penelitian ini adalah rendemen yang diharapkan memiliki jumlah yang banyak.

Hal tersebut terjadi karena dalam proses delignifikasi ada komponen polisakarida yang terlarut di dalam pelarut. Menjelang akhir delignifikasi dapat terjadi kehilangan polisakarida, sehingga mengurangi rendemen. Pelarut sodium hipoklorit $(\mathrm{NaOCl})$ dalam penelitian ini diduga mampu memutus ikatan kovalen dan melarutkan selulosa, sehingga terjadi penurunan. Hubungan antara penurunan berat kering dengan konsentrasi pelarut dalam delignifikasi dikaitkan dengan ikatan komplek lignin-polisakarida, jika konsentrasi yang digunakan tinggi maka dapat terjadi kehilangan banyak polisakarida.

\section{Ekstraksi Polisakarida (Gula Kompleks)}

$\begin{array}{rrrrr} & \text { Proses } & \text { ekstraksi } & \text { dapat merusak } \\ \text { dinding } & \text { sel } & \text { tanaman } & \text { dan } & \text { akan }\end{array}$ mempermudah akses enzim ataupun agen kimia jika non enzimatik pada polisakarida tanaman (Gray et al. 2006). Proses pretreatment pada penelitian ini bertujuan untuk mempermudah proses untuk mencapai tahap hidrolisis. Gray et al. (2006) menyatakan bahwa biomassa yang tidak ditreatment akan bersifat recalcitrant pada proses pemecahan oleh enzim. Apabila non enzimatik maka akan mempersulit akses agen kimia untuk memotong gula kompleks.

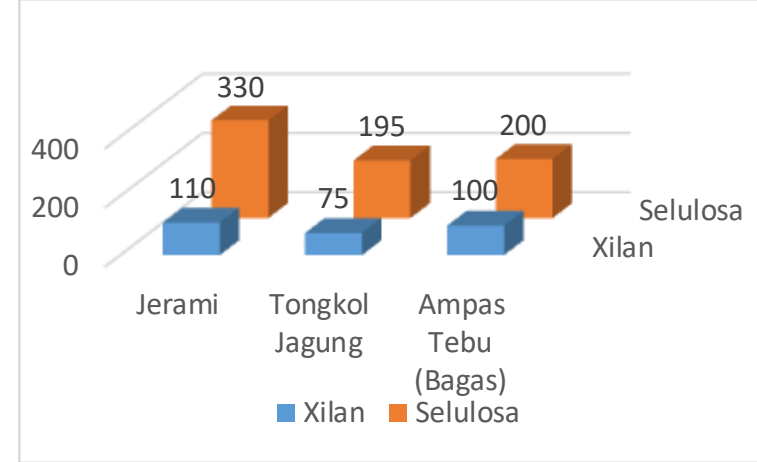

Gambar 2. Grafik perbandingan hasil xilan dan selulosa dalam satu tahapan ekstraksi xilan.

Berdasarkan hasil dari tahapan ekstraksi xilan (Gambar 2) dari tiga jenis limbah lignoselulosa, diperoleh rendemen xilan terbanyak yakni jerami sebanyak $110 \mathrm{~g}$ dan terendah yakni tongkol jagung sebanyak 75 g. Hasil xilan terbanyak pada jerami juga berbanding lurus dengan perolehan rendemen selulosa, yakni sebanyak $330 \mathrm{~g}$. Hal tersebut juga berlaku pada tongkol jagung dan bagas tebu, dimana rendemen xilan berbanding lurus dengan selulosa.

Xilan atau hemiselulosa berada diantara lignin dan kumpulan serat selulosa. Lapisan xilan berikatan secara kovalen dengan lignin dan non-kovalen dengan selulosa melalui ikatan hidrogen (Beg et al. 2001). Apabila delignifikasi dapat mengurangi jumlah lignin, maka secara otomatis ikatan xilan dengan selulosa akan mudah terputus. Pemecahan rantai polisakarida tersebut dengan lignin akan memberikan peningkatan jumlah hemiselulosa yang dihasilkan. Tahap produksi hemiselulosa, dalam proses delignifikasi terjadi kehilangan selulosa yang diakibatkan oleh degradasi oksidatif maupun hidrolitik. Penurunan jumlah selulosa maupun lignin dikarenakan terlarut di dalam $\mathrm{NaOCl}$, sedangkan polisakarida yang mengendap adalah xilan. Kehilangan selulosa terjadi kemungkinan karena terlarut sebagai kompleks lignin-polisakarida.

\section{Purifikasi (Pemurnian) Xilan}

Pemurnian hasil ekstraksi xilan menjadi penting karena masih terdapatnya komponen-komponen pengotor lain, seperti selulosa dan lignin. Substansi $\gamma$-selulosa ialah nama untuk bagian yang tetap larut meskipun dalam larutan yang dinetralkan. 
Selama ekstraksi dengan larutan alkali kuat, maka bagian selulosa yang memiliki berat molekul rendah dapat terlarut bersama-sama dengan hemiselulosa.

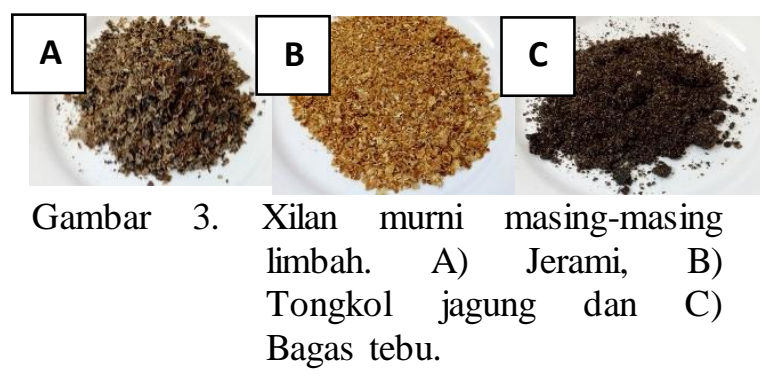

Pretreatment dalam penelitian ini bertujuan untuk mendapatkan ekstraksi produk polisakarida xilan yang terkandung di dalamnya. Xilan yang dihasilkan nantinya dapat digunakan sebagai substrat dalam reaksi enzim, atau substrat dalam proses hidrolisis secara kimia dan produk yang diperoleh adalah monosakarida yang dapat digunakan sebagai bahan fermentasi untuk bioetanol, probiotik, prebiotik, dan lain sebagainya. Oleh karena itu pretreatment sangat penting karena berpengaruh dengan proses hidrolisis selanjutnya yakni hidrolisi dan fermentasi bioethanol (Gambar 3).

\section{KESIMPULAN DAN SARAN}

\section{Kesimpulan}

1.Jumlah rendemen terbanyak dari proses delignifikasi adalah tongkol jagung yakni sebesar $860 \mathrm{~g}$ dari total awal sebelum didelignifikasi $1000 \mathrm{~g}$, dengan presentase penurunan yang terkecil yakni sebesar $14 \%$.

2. Jumlah rendemen xilan terbanyak yaitu jerami sebanyak $110 \mathrm{~g}$, sedangkan untuk selulosa juga diperoleh oleh jerami yaitu sebanyak 330 g. Hal tersebut menunjukkan bahwa jumlah terbanyak pada rendemen xilan selalu berbanding lurus dengan jumlah selulosa. Kesimpulan tersebut di perkuat dengan hasil pada dua jenis limbah lainnya, yakni berbanding lurus.

3. Jumlah rendemen xilan hasil pemurnian (purifikasi) terbanyak yaitu bagas tebu sebanyak 86 g. Sebenarnya hasil yang diperoleh tidak terlalu signifikan jika dibandingkan dengan xilan murni jerami yakni sebesar 85 g. Oleh karena itu, jika disimpulkan substrat yang paling banyak untuk produksi enzim adalah jerami, hal tersebut jika dilihat dari total jumlah xilan dan selulosa yang telah diperoleh lebih besar dari pada hasil bags tebu. Semakin banyak jumlah rendemen yang diperoleh maka akan berbanding lurus dengan perolehan hasil dalam produksi enzim.

\section{Saran}

1.Untuk mengetahui kualitas tingkat kemurnian xilan maupun selulosa yang dihasilkan masing-masing limbah, diperlukan pengujian kromatografi lapis tipis (KLT) atau Thin Layer Chromatograpy (TLC). Dimana produk hasil penelitian ini dibandingkan dengan produk bermerek yang sudah terstadarisasi. Sehingga selain jumlah rendemen terbanyak, kualitas produk juga dapat mendukung data perolehan yang lebih signifikan.

2.Mengingat jumlah sekali perlakuan pretreatment masing-masing limbah adalah $1000 \mathrm{~g}$, dengan hasil pencampuran dengan pelarut maupun justifikasi $\mathrm{pH}$ yang mencapai 10 sampai 15 Liter per sampel, proses sentrifugasi tidak efisien jika diterapkan dalam skala laboratorium maupun skala besar (scale up). Oleh karena itu metode ini kurang tepat jika diterapkan dalam produksi skala besar, butuh penelitian lebih lanjut untuk mencari metode yang lebih efisien namun tetap memiliki kualitas dan hasil yang serupa.

3.Apabila hanya untuk pengujian skala laboratorium, jumlah biomassa awal 1000 $\mathrm{g}$ dalam penelitian ini dinilai terlalu banyak. Oleh sebab itu, apabila penelitian bersifat membandingkan beberapa jenis limbah kemudian tidak disarankan mencapai berat 1000 g. Lebih efisien hanya mencapai 300 sampai $500 \mathrm{~g}$ per perlakuan treatment.

\section{DAFTAR PUSTAKA}

Chapman, J.S. 2003. Biocide resistance mechanisms. Int Biodeter Biodegr. 51:133- 138 . 
Beg, Q.K., M. Kapoor, L. Mahajan, and GS. Hoondal. 2001. Microbial xylanases and their industrial applications: a review, Appl Microbiol Biotechnol. 56:326-338.

Gray, K.A, Zhao L, Emptage M. 2006. Bioethanol. Chem Bio J. 10: 141-146.

Iranmahboob, J., F. Nadim, and S. Monemi, 2002, Optimizing acid-hydrlysis: a critical step for production of ethanol from mixed wood chips, Biomass and Bioenergy. 22: 401404.

Lee, Y.J. 2003. Oxidation of sugarcane bagas using a combination of hypochlorite and peroxide [Thesis], Korea (KR): Submitted to The Graduate Faculty of theLouisiana State University dan Agricultural dan Mechanical College.

Richana, N. 2002. Produksi dan prospek enzim xilanase dalam pengembangan bioindustri di Indonesia, Buletin AgroBio. 1:29-36.
Richana, N., T.T. Irawadi, MA Nur, MA., Sailah, I., Syamsu, K., and Arkenan, Y. 2007. Ekstraksi xilan dari tongkol jagung. J. Pascapanen. 4(1):38-43.

Riyanti, E.I. 2008. Biomassa sebagai bahan baku bioethanol. J Litbang Pertan. 28(3).

Sudiyani, Y., Heru R., Alawiyah, S. 2010. Pemanfaatan biomassa limbah lignuselulosa untuk bioetanol sebagai sumber energi baru terbarukan. Ecolab. 4(1):1-54.

Sun, Y., and Cheng, J. 2002. Hydrolysis of lignocellulosic materials for ethanol production: a review. Biores Technol.83:1-11.

Su, Z.Q., Bu, L.X., Zhao,D.Q., Sun, R.C., and Jiang J.X. 2012. Processing lespedeza stalks by pretreatment with low severity steam and post treatment with alkaline peroxide. Industrial Crops and Product.36, $1-8$. 